\title{
La voz en los ensayos audiovisuales de Carolina Astudillo. Análisis de El Gran Vuelo (2014) y Ainhoa, yo no soy esa (2018) a partir del esquema comunicativo de Julia Kristeva ${ }^{1}$
}

\section{The voice in Carolina Astudillo's essay films. Analysis of the works El Gran vuelo (2014) and Ainhoa, yo no soy esa (2018) according to Julia Kristeva's communicative scheme}

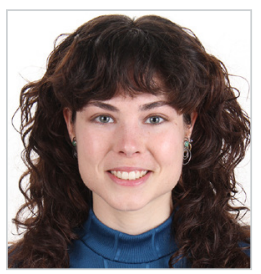
\author{
la $3^{a}$ Convocatoria PhDay Complutense. \\ Universidad Complutense de Madrid, España \\ esthep02@ucm.es \\ ORCID: 0000-0001-8647-9304
}

Esther Pérez Nieto. Contratada predoctoral (FPU) del Programa de Doctorado en Comunicación Audiovisual, Publicidad y Relaciones Públicas de la Universidad Complutense de Madrid. Departamento de Ciencias de la Comunicación Aplicada (CAP). Facultad de Ciencias de la Información. Premio Extraordinario 1a de promoción en el Grado de Comunicación Audiovisual por la UCM y Beca de Excelencia Máster, obtuvo el Premio Áccesit en

Recibido: 27/10/2020 - Aceptado: 01/03/2021 - En edición: 29/03/2021 - Publicado:14/06/2021 Resumen:

Este artículo estudia la voz en el cine de Carolina Astudillo a través del análisis de sus dos largometrajes El gran vuelo (2014) y Ainhoa, yo no soy esa (2018). Sus trabajos contienen características atribuidas al ensayo audiovisual, como es el uso de técnicas y materiales diversos, el desarrollo de un discurso asistemático y la autorreflexividad. Esta forma de hacer cine resulta especialmente adecuada para la exploración de temáticas que preocupan a la autora. Aplicaremos el esquema comunicativo desarrollado por Julia Kristeva en su Semiótica (1969) para identificar las diferentes voces en estas dos películas. Con esto probaremos que la voz de la directora se filtra a través de las de sus personajes, estableciendo un diálogo con ellos y al mismo tiempo convirtiéndolo en una técnica de exploración de sí misma a modo de espejo.

Palabras clave:

Ensayo cinematográfico; voz; Julia Kristeva; Carolina Astudillo; autorreflexividad.
Received: 27/10/2020 - Accepted: 01/03/2021 - Early access: 29/03/2021 - Published: 14/06/2021 Abstract:

This article studies the voice in Carolina Astudillo's cinema by analysing her two feature films El gran vuelo (2014) and Ainhoa, yo no soy esa (2018). Her works contain characteristics of an audio-visual essay, such as using different techniques and materials, an asystemic discourse, and self-reflective speech. This form of filmmaking is particularly suitable for exploring themes that concern the author. We will apply the communicative scheme developed by Julia Kristeva in Semiotics (1969) to identify the different voices in these two films. Thus, we will demonstrate how the director's voice is filtered through her characters, establishing a dialogue with them while at the same time turning it into a mirror-like technique for self-exploration.

\section{Keywords:}

Audio-visual essay; voice; Julia Kristeva; Carolina Astudillo; selfreflectivity.

1 Esta investigación ha recibido el apoyo económico del Ministerio de Economía y Competitividad y el Fondo Europeo de Desarrollo Regional dentro del Programa Estatal de Fomento de la Investigación Científica y Técnica de Excelencia en el marco del proyecto de investigación "El Ensayo en el Audiovisual Español Contemporáneo” (Ref. CSO2015-66749-P). También ha sido financiada por el Ministerio de Ciencia, Innovación y Universidades gracias a una Ayuda para la formación del profesorado universitario (FPU).

\section{Cómo citar este artículo:}

Pérez Nieto, E. (2021). La voz en los ensayos audiovisuales de Carolina Astudillo. Análisis de El Gran Vuelo (2014) y Ainhoa, yo no soy esa (2018) a partir del esquema comunicativo de Julia Kristeva. Doxa Comunicación, 32, pp. 207-224.

https://doi.org/10.31921/doxacom.n32a10 


\section{Objeto de la investigación}

Este estudio nace en el contexto del proyecto de investigación: "El Ensayo en el Audiovisual Español Contemporáneo" (Ref. CSO2015-66749-P). Una de las metas principales del proyecto era contribuir a la definición del ensayo cinematográfico. Tratamos de explorar dicha definición mediante el análisis de una muestra de 200 títulos, que se clasificaron como películas de no ficción en un rango desde documentales hasta obras experimentales. El resultado, más que una definición cerrada, fue una serie de características presentes en mayor o menor grado. El estudio completo se recoge en el artículo El ensayo en los medios audiovisuales españoles contemporáneos: definición, producción y tendencias (Communication \& Society, 2020), escrito por el director del proyecto Norberto Mínguez Arranz y la profesora Cristina Manzano Espinosa.

Nuestro objetivo es estudiar la voz en la obra de Carolina Astudillo, cineasta chilena que se trasladó a Barcelona para finalizar sus estudios, donde es docente y ha desarrollado su obra documental hasta la fecha. Sus películas se han centrado en el rescate de la memoria histórica de las mujeres en la guerra civil española y en el llamado periodo de la transición. Carolina ha dirigido siete cortometrajes hasta la fecha: De Monstruos y faldas (2008), Lo Indecible (2012), Maleza (2015), El deseo de la civilización: Notas para El gran vuelo (2014), Naturaleza muerta (2019), Un paseo por New York Harbor (2019) y Herencia (2020). A estos se suma la pieza El descaro y el largometraje Canción de una dama en la sombra (2021), ambos en postproducción, y sus dos largometrajes El gran vuelo (2014) y Ainhoa, yo no soy esa (2018). Centraremos nuestro análisis sobre estas dos últimas películas por haber sido las más premiadas en festivales y más ampliamente referidas por los medios de comunicación. Consideramos, además, que El gran vuelo y Ainhoa, yo no soy esa, actúan como síntesis de las temáticas que han preocupado a la directora y, al mismo tiempo, como ejemplo de los rasgos formales más característicos de su cine, como son el montaje a partir de material de archivo y metraje encontrado-found footage- y el uso sistemático de la voz, propia o ajena, como testimonio de verdad que activa mecanismos de identificación. El cine de Carolina pone de manifiesto un especial interés por el lenguaje y en concreto la voz como herramienta para entretejer la memoria personal con la memoria histórica. Podemos relacionar esta metodología de trabajo como directora, que recurre constantemente a los textos orales y escritos, con el concepto de ideologema, definido por J. Kristeva como "esa función intertextual que se puede leer 'materializada' en los diferentes niveles de la estructura de cada texto, y que se extiende a todo lo largo de su trayecto dándole sus coordenadas históricas y sociales" (Semiótica I, 1981, p. 148). El hispanista francés Edmond Cros actualiza el concepto de ideologema en la década de 1990, refiriéndose al sujeto cultural como aquel que produce-interpreta textos dentro de la cultura, de acuerdo a un pasado y un horizonte histórico (2005, p. 41). Más adelante, en La sociocrítica, Cros define ideologema como:

Un microsistema semiótico-ideológico subyacente a una unidad funcional y significativa del discurso. Esta última se impone, en un momento dado, en el discurso social, donde presenta una recurrencia superior a la de los otros signos. El microsistema así planteado se organiza alrededor de dominantes semánticas y de un conjunto de valores que fluctúan a merced de las circunstancias históricas (Cros, 2009, p. 215).

Hemos tomado el cine de Carolina Astudillo como ejemplo de una generación de directoras que en las últimas dos décadas han explorado aspectos comunes a la historia de las mujeres, reivindicando sensibilidades y preocupaciones habitualmente al margen de los relatos históricos oficiales. Entre ellas destacamos a Virginia García del Pino, Nuria Ibáñez, 
Mercedes Moncada, Tatiana Huezo, Lucía Gajá, Lupe Pérez García, María Ruido, Xiana do Teixeiro, Diana Toucedo y Marcela Zamora. A través de sus películas han dado voz a estas mujeres relatoras, poniendo en el centro la herencia de una cultura oral todavía viva y una ética de los cuidados. Sus trabajos centran la atención en territorios de Latinoamérica y de España y obedecen en su mayoría a códigos narrativos del cine documental, pero la constante hibridación de técnicas y el uso de distintos materiales los sitúa muy cerca del ensayo audiovisual. Como una forma de hacer cine centrada en el propio proceso de exploración -ensayar-, resulta especialmente adecuado para un acercamiento a sus preocupaciones desde el arte gracias a su asistematicidad característica y al componente autorreflexivo.

Con este análisis centrado en la importancia de la voz, tanto de la propia autora-narradora, como de sus personajes, entendemos la palabra en una relación anafórica con la realidad, que como explicó Julia Kristeva en su Semiótica: "no toman su significación más que como enchufes con ese texto-fuera-del-texto-presente [...] A través de la anáfora, la variable hace surgir, en el texto escrito, los textos ausentes (la política, la economía, los mitos)” (1981, p. 106). La voz de Carolina Astudillo está siempre presente, de forma explícita o mediatizada a través de la de sus personajes. En sus películas, la cotidianidad, los sentimientos y las experiencias íntimas de las mujeres protagonistas funcionan como "enchufe" con los acontecimientos históricos. El amplio uso de citas en cartas, diarios y conversaciones hace las veces de homenaje y, al mismo tiempo, es una llamada a la identificación: "Por eso quise incluir mi experiencia en esta película, ya que la lectura de las vivencias de otras mujeres nos puede incitar a tomar el control de nuestras vidas" (Ainhoa, yo no soy esa. 01:04:45). La polifonía, de la que nos habla Julia Kristeva al referirse a los textos dialógicos, se convierte en el cine de Carolina Astudillo en una técnica de exploración de sí misma a través de los testimonios de otros.

\section{Marco teórico}

Uno de los primeros trabajos académicos de Julia Kristeva fue una extensa revisión de las teorías del filólogo ruso Mijaíl Bajtín en su artículo "Bakhtine, le mot, le dialogue et le roman" publicado en la revista Critique en 1967. Gracias a este texto, junto con otras publicaciones de Tzvetan Todorov, la terminología de Bajtín fue conocida en el ambiente intelectual francés de los años sesenta. En su artículo, J. Kristeva combinó las nociones bajtinianas sobre el dialogismo literario con los conceptos de la semiótica estructuralista de Ferdinand de Saussure. Fue aquí donde aportó su definición de intertextualidad: "Todo texto se construye como mosaico de citas, todo texto es absorción y transformación de otro texto. En lugar de la noción de intersubjetividad se instala la de intertextualidad, y el lenguaje poético se lee, al menos, como doble" (1981, p. 190). Quince años después, Gérard Genette desarrolló el concepto de intertextualidad en su famoso libro Palimpsestes. La littérature au second degré (1982). Para Kristeva la literatura puede ser un campo de estudio histórico y social, imposible de categorizar en un sistema cerrado de signos -estructuralismo-, por lo que pronto destacó en la llamada corriente postestructuralista. Sus primeras obras responden a un periodo de inquietud epistemológica, puesto que en ellas se plantean problemas metodológicos en torno a la semiótica como ciencia crítica (Bohórquez, 1997). En 1969 publicó Sèméiôtikè. Recherches pour une sémanalyse (1969) (Semiótica I y II, 1981)².

2 Hélène Volat ha elaborado una lista detallada de todas las ediciones de las obras publicadas por Julia Kristeva, disponible en la siguiente dirección: https://bit.ly/3b9CCdQ 
En su Semiótica, Kristeva explicará que la información de un texto se transfiere de escritor a lector a través de una serie de códigos que involucran otros textos, por ello, establecerá la "necesidad de introducir las matemáticas en la semiótica, de hallar un sistema de siglas -= de números- cuya articulación describiría el funcionamiento de las prácticas semióticas y construiría el lenguaje de una semiótica general" (1981, p. 72). Este acercamiento entre la lingüística y el lenguaje matemático como sistema no ha estado exento de polémica. Destaca la crítica de los físicos Alan Sokal y Jean Bricmont, que en su libro Impostures intellectuelles (Imposturas intelectuales, 1999) denunciaron el uso de términos técnicos matemáticos y del terreno de la física en las obras de Kristeva, junto con todo el grupo de psicoanalistas y filósofos que a finales del s. XX conformaban el grupo de la llamada French Theory en los Estados Unidos: Jacques Lacan, Gilles Deleuze, Jean Baudrillard, Luce Irigaray, Jacques Derrida, Paul Virilio y Félix Guattari, entre otros. El libro de Sokal y Bricmont subraya el problema del relativismo cognitivo en sus obras, junto con un uso pretencioso e inadecuado de términos científicos, que son destinados a impresionar a un lector no especializado en las ciencias matemáticas y con la intención, según ellos, de "surpasser Lacan pour ce qui est de la superficialité de l'erudition" (1999, p. 87). A su vez, Sokal y Bricmont fueron atacados en varios artículos publicados en medios de comunicación, como Le Monde o Libération. La propia Kristeva respondió con un escrito en Nouvel Observateur. Une désinformation (1997, p. 122) donde denuncia la francophobie de ambos autores. En este artículo, Kristeva elogia los numerosos estudios críticos e interpretaciones de colegas de todo el mundo sobre sus obras y cita un entonces reciente estudio de Hélène Volat en el que se hace referencia a 660 investigaciones basadas en sus obras y publicadas entre 1970 y 1994 (publicado por Des Lettres Modernes, Les carnets bibliographiques en 1996).

Los estudios sociocríticos toman impulso entre los años sesenta y setenta del siglo XX en Francia, como resultado de una coyuntura intelectual que desembocó en las protestas de Mayo de 1968. En París y Montpellier destacan los nombres de Claude Duchet y Edmond Cros (Chicharro, 2007, p. 715). En este contexto, comenzaron a insertarse aspectos de la sociología en el estudio de obras literarias, analizando sus implicaciones históricas y culturales más allá del texto. Aquí aparece la definición del término ideologema, desarrollada por Kristeva y más adelante por Edmond Cros. Según Carmen Ávila y Francisco Linares, aunque ambos, Cros y Kristeva, parten de la concepción bajtiniana de ideologema -textos dialógicos-y de la semántica estructural, con la concepción de signo desarrollada por Ferdinand de Saussure, difieren en el rango de acción del este ideologema, ya que Cros centra su aplicación en el funcionamiento ideológico del discurso social (2010, p. 108). En palabras de Ávila y Linares: "Esta escapa [la dimensión connotativa social] a las preocupaciones de la lexicología y lexicografía al uso, siendo cosa de la interpretación particular de los textos. Tiene que ver con la semiotización de la ideología o, lo que es lo mismo, con la producción cultural de signos ideológico-sociales” (2010, p. 109). La noción de ideologema en Cros se relaciona con sus teorías sobre el texto cultural y el sujeto cultural, pero no debemos olvidar su formación filológica. Consideramos, sin embargo, que J. Kristeva también subraya las relaciones inseparables de significado entre todo análisis textual y la estructura social en la que son producidos dichos discursos. Para Kristeva, "[l]a aceptación de un texto como un ideologema determina la actividad misma de una semiótica que, estudiando el texto como una intertextualidad lo piensa así en (el texto de) la sociedad y la historia" (1981, p. 148). Julia Kristeva define el texto como: "un instrumento translingüístico que redistribuye el orden de la lengua, poniendo en relación un habla comunicativa que apunta a la información directa, con diferentes tipos de enunciados anteriores o sincrónicos" (1981, p. 147). A continuación, se refiere al texto como una productividad, lo cual se explica por dos motivos: 
1. Porque su relación con la lengua en la que se inserta es redistributiva-destructivo-constructiva-, con lo que es más adecuado abordar su análisis a través de la aplicación de categorías lógicas, más que lingüísticas. Esto reitera la constante crítica de Kristeva a la lingüística estructural -postestructuralismo-.

2. Porque es una intertextualidad, es decir, una permutación de textos donde se cruzan enunciados tomados de otros textos, se mezclan y se neutralizan unos a otros.

Si aplicamos el espíritu crítico de las teorías postestructuralistas al texto cinematográfico, encontramos múltiples posibilidades de análisis desde la ruptura de categorías que plantea el cine-ensayo. La línea que separa la ficción de la no ficción siempre ha sido difícil de trazar, a menudo se ha hecho con motivos de captación de público y está en constante redefinición (Mínguez, 2014). A este pueden sumarse otros estudios sobre cine que analizan las hibridaciones entre ficción y no ficción (Carrera y Talens, 2018; Cerdán y Torreiro, 2007; Ward, 2005). Josep María Català, en Estética del ensayo. La forma ensayo, de Montaigne a Godard (2014), señala que esta manera de hacer cine problematiza la fragmentación y que es especialmente un fenómeno de los productos audiovisuales contemporáneos (2014, p. 278). Unas líneas más adelante afirmará: "El film-ensayo no acude a la mezcla de realidad y ficción como recurso estilístico o expresivo, sino que está instalado en ella por su propia configuración” (2014, p. 279). Català utiliza como ejemplo un clásico, Fake (1973), dirigido y protagonizado por Orson Welles y que ha sido casi siempre catalogado como documental o docudrama, para referirse a la incertidumbre que el film inserta en el espectador, sobre la que este se debate "como factor emocional", no sabiendo qué es o no real. De esta forma: "Es posible que, finalmente, el espectador no llegue a ninguna conclusión definitiva sobre el tema planteado, pero lo que no podrá ignorar es que la película le ha propuesto una reflexión sobre él, por ambigua que sea" (2014, p. 279). De acuerdo con el análisis llevado a cabo por el grupo de investigadores del Proyecto ENAVEC, podemos señalar siete características del ensayo cinematográfico (Mínguez y Manzano, 2020, p. 23):

1. Construcción de una línea de pensamiento que se expresa a través de la forma. Esto subraya la importancia de la forma particular de expresión de cada autor/ autora, revelando una voluntad de estilo.

2. Autorreflexividad: el cine como herramienta de autoconocimiento.

3. Discurso asistemático, no científico, no clausurado: "el ensayo traduciría en este sentido las reflexiones de las teorías fílmicas que definen el paradigma moderno (Pasolini y Rohmer, 1971; Bordwell, 1996), frente al paradigma narrativo clásico y que asumirían un tratamiento incompleto o tentativo de un tema".

4. Focalización subjetiva, punto de vista autoral: "consideramos las elecciones de la perspectiva narrativa a partir de la clasificación propuesta por A. Gaudreault y F. Jost (1995), adaptada a las particularidades del discurso cinematográfico, frente a otras clasificaciones basadas en el discurso literario, como las de Todorov (1966) o Genette (1970)".

5. Discurso crítico como herramienta de intervención estética, social o incluso política: el ensayo puede ser utilizado en cierto modo como un manifiesto, ya que trasciende la autorreferencialidad.

6. Pacto ensayístico: la película establece un diálogo entre el autor y el público. Necesita una participación activa del espectador. Para cumplir este propósito, utiliza una variedad de herramientas, entre las cuales la palabra escrita y la voz en off están entrelazadas. 
7. Rompe con las formas audiovisuales más convencionales. Por eso este tipo de películas escapan a clasificaciones cerradas. "El grado de experimentalidad sirve como indicador de la capacidad del ensayo para renovar el lenguaje audiovisual, así como para valorar su carácter de producto audiovisual destinado a un público especializado".

Laura Rascaroli comienza su libro How The Essay Film Thinks (2017) explicando que algunos de los rasgos que se atribuyen al ensayo cinematográfico ya fueron enunciados en 1940 por Hans Richter en su artículo Der Filmessay, eine neue form des Dokumentarfilm, como son las transgresiones y cruce de fronteras, una huida de las convenciones, libertad inventiva y de expresión, complejidad y reflexividad (2017, pp. 2-3). A su vez, Nora Alter afirma que una de las características principales del ensayo es su lucha por librarse de toda restricción, ya sea formal, conceptual o social (1996, p. 171). Según Josep María Català: "El film-ensayo es un cine de pensamiento, es decir, no solo un cine que piensa, sino un cine a través del que se piensa" (2019, p. 17). Rascaroli desarrolla lo que ella llama "the method of between", término inspirado por los estudios de Gilles Deleuze sobre el poder significante de la intersticialidad para generar un nuevo pensamiento fílmico (Deleuze, 1986). Es el lugar donde el ensayo se sitúa como un resquicio que escapa a la comprensión. Deleuze coloca el intersticio en este lugar de incomodidad desde el que provocar un pensamiento verdaderamente nuevo - "Cinema as image of thought" (Rascaroli, 2017, p. 9). Con anterioridad a la publicación de How The Essay Film Thinks, Raymond Bellour (2012) utiliza un concepto muy similar al de Laura Rascaroli: in-between, para referirse a la idea de un artista que se sitúa entre el arte visual y la escritura como portador de la memoria cultural.

\section{Metodología}

Basándose en el análisis dinámico de los textos de M. Bajtín (1978) sobre el dialogismo literario, Kristeva establece una doble tipología de los discursos (1981, p. 206). Por un lado, el discurso monológico, que comprende: a) el modo representativo de la descripción y de la narración épica, b) el discurso histórico y c) el discurso científico. En los tres, el sujeto asume el papel de un ser superior, de un Dios, "el discurso se niega a volverse sobre sí mismo -a 'dialogar"”-. Por otro lado, el discurso dialógico comprende tres categorías: a) el carnaval, b) la sátira menipea y c) la novela polifónica. Aquí el carnaval es comparado con el dionisismo nietzschiano, se desarrolla en un escenario cínico donde se imponen sus leyes dialógicas por encima de la voz de un Dios: "en el carnaval el sujeto resulta aniquilado: en él se cumple la estructura del autor como anonimato que crea y se ve crear, como yo y como otro, como hombre y como máscara” (1981, p. 209).

Sin embargo, a pesar de colocar el discurso histórico dentro de las categorías monológicas, parece dejar un resquicio para el diálogo. "Toda narración, incluida la de la historia y la ciencia, contiene esa diada dialógica que forma el narrador con el otro” (1981, p. 205). Así pues, en el apartado El dialoguismo inmanente de la palabra denotativa o histórica, del capítulo séptimo de su Semiótica, afirma que ante un análisis psicoanalítico y semántico del lenguaje, "el dialoguismo es coextensivo a estructuras profundas del discurso" (1981, p. 202) y que el autor deja en la escritura la huella de un diálogo consigo mismo (con el otro yo), desdoblándose así en sujeto de la enunciación/sujeto del enunciado. Partiendo de la base de análisis de todo proceso comunicativo como un diálogo entre un sujeto (S) y un destinatario (D), Julia Kristeva dibuja este esquema: 
Figura 1. Esquema comunicativo de Julia Kristeva

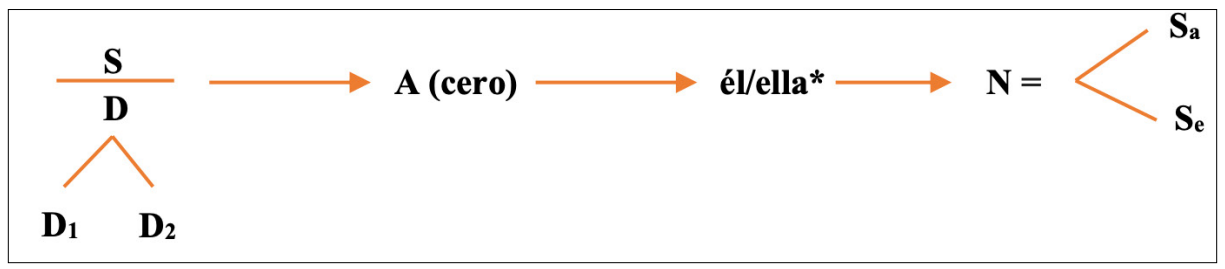

Fuente: Semiótica I (1981, p. 204) *Hemos añadido el pronombre ella

El sujeto de la narración [S], en el acto de narrar, se dirige necesariamente a un destinatario [D]. Este, a su vez, se convierte en sujeto de la lectura de ese texto-narración y representa una "entidad con doble orientación: significante en su relación con el texto y significado en la relación del sujeto de la narración con él” (Kristeva, 1981, p. 203). Esta diada [D y $\mathrm{D}_{2}$ ] construye un sistema de código al modo de las matemáticas. El sujeto de la narración [Autor/Autora] en este sistema, desaparece, se hace anónimo [A cero] y se mediatiza a través de un personaje [él/ella*] que se convertirá en nombre propio [N: ej. Medea]. El personaje se desdoblará a su vez en sujeto de la enunciación $\left[\mathrm{S}_{\mathrm{a}}\right.$ ] y sujeto del enunciado [S $\mathrm{S}_{\mathrm{e}}$.

La divergencia entre el qué -historia- y el cómo, es decir, el acto de narrar, la enunciación -discurso- ha sido tratado por un amplio número de narratólogos durante el siglo XX. Por citar algunos, Tzvetan Todorov distingue entre historia y relato (1966), Roland Barthes definió una triada más compleja: nivel de las funciones, nivel de las acciones y nivel de la narración (1966), Gérard Genette distinguió entre historia, relato y narración (1989 y 1983); Seymour Chatman utiliza las categorías de historia y discurso (1978) y Mieke Bal de fábula, historia y texto (1985). Julia Kristeva conoció estos debates terminológicos. Émile Benveniste desarrolló su teoría de la enunciación entre 1960 y 1970 como una crítica a las limitaciones de la lingüística de F. de Saussure, que analizó de forma separada la lengua y el habla. Benveniste formuló una teoría del lenguaje que se ocupaba especialmente de la relación del sujeto con el discurso, con el acto de enunciación entendido como la lengua puesta en acción por “un acto individual de utilización” (2004, p. 83). Por ello, establecerá que el sujeto se constituye gracias al otro, para que exista un yo siempre se presupone la existencia de un tú al que se dirige (2004, p. 181). Tomamos entre las características del cine-ensayo arriba enunciadas las de pacto ensayístico [6], y autorreflexividad [2] para aplicarlas al análisis de la voz en dos largometrajes de Carolina Astudillo: El gran vuelo (2014) y Ainhoa, yo no soy esa (2018). Entendemos esta voz como un discurso doblemente dialógico de la autora: con el espectador / consigo misma-sus personajes -sujeto de la enunciación-sujeto del enunciado-. En palabras de J. Kristeva: "El dialoguismo sitúa a los problemas filosóficos en el lenguaje, y más exactamente en el lenguaje como una correlación de textos, como escritura-lectura que va a la par con una lógica no aristotélica, sintagmática, correlacional, 'carnavalesca'” (1981, p. 224). Por otro lado, tomamos también la característica de discurso asistemático, no clausurado [3] porque en ella podemos inscribir lo que J. Kristeva llama ambivalencia, tomando también este término de Bajtín, donde coexisten “a la vez 'doble de lo vivido' (realismo, épica) y ‘vivido’ mismo (exploración, lingüística, menipea)” (1981, p. 224). Consideramos que esta coexistencia entre el discurso histórico y el discurso ficcional (menipea, novela polifónica) es perfectamente trasportable del terreno de la literatura, donde fue enunciado, al análisis del film-ensayo, que toma su nombre y características del ensayo literario 
como forma de escritura iniciada por Michel de Montaigne en el siglo XVI. En sus Essais, Montaigne intenta hacer una investigación filosófica de sí mismo, a modo de espejo. En este análisis quedan de manifiesto las complejas relaciones entre palabra e imagen, que José Luis Sánchez Noriega aborda en su texto seminal De la literatura al cine. Teoría y análisis de la adaptación (2000). Noriega señala que el cine emplea tres registros: el visual, el sonoro y la escritura. No solo aludimos a lo textual mediante la presencia de palabras -rótulos en los orígenes del cine silente- en la pantalla, sino que "el texto fílmico se construye también con el registro verbal” (2000, p. 39, [énfasis original]). El autor hace hincapié en el carácter no unívoco de la imagen, es decir, que a pesar de la asunción generalizada de que la palabra está situada en un nivel de abstracción y por el contrario la imagen remite de forma directa a un referente, lo cierto es que la imagen "es susceptible de ambigüedad en el momento en que la banda sonora que la acompaña puede proporcionarle sentidos muy diferentes" (2000, p. 39).

\section{Análisis}

Carolina es periodista, además de directora, se diplomó en Estudios de Cine por la Universidad Católica de Chile y cursó el Máster en Documental Creativo de la Universitat Autònoma de Barcelona, donde realizó su primer cortometraje, De monstruos y faldas (2008), coproducido por la UAB y Localia Televisión. La directora descubrió entonces la historia de la Prisión de Les Corts, donde muchas mujeres fueron encarceladas por motivos políticos tras la guerra civil española y de esta forma se tejió el hilo conductor de su cine, ligado a la investigación sobre la historia de las mujeres y la memoria. Más adelante, en 2014, se estrenará El Gran Vuelo, su primer largometraje y también conectado con Les Corts, prisión de la que escapó su protagonista, Clara Pueyo Jornet, una joven republicana miembro de la junta directiva del Partido Socialista Unificado de Catalunya y secretaria de Socorro Rojo Internacional. Fue detenida durante la dictadura franquista y su huida se conoció como "El Gran Vuelo". Nada se supo de ella desde entonces. La película comienza con la voz de un locutor que afirma: "No podemos escuchar la voz de nuestros muertos, solo en recuerdos, sueños o en una imagen" (min. 01:09). Esta frase actúa como una declaración de intenciones: a través de imágenes de archivos familiares e institucionales de la España franquista, junto con las pocas fotografías conservadas de Clara Pueyo y sus hermanos, la directora nos acerca a los acontecimientos que rodearon la vida de la protagonista hasta su desaparición, así como a su universo íntimo, a sus inquietudes y miedos, al trauma de la guerra y a sus motivaciones para una vida dedicada a la militancia.

En El Gran Vuelo distinguimos dos voces: la de Sergi Dies en castellano, como narrador omnisciente al estilo del documental clásico y la de María Cazes, que interpretará a Clara Pueyo y nos hará llegar sus reflexiones más íntimas, en castellano y en catalán. A continuación, nos proponemos explicar por qué estas dos voces representan dos puntos de vista de la directora que dialoga con el espectador a través de ellas. Para Justo Villafañe y Norberto Mínguez (2009, p. 195), partiendo de las teorías sobre la estructura narrativa de Seymour Chatman (1990), el autor implícito en literatura se materializa a través de un agente que muestra o cuenta la historia. Rimmon-Kenan (2005) reproduce el esquema que Chatman creó para su Story and Discourse (1978) en el que efectivamente el autor y el lector real del texto quedan fuera del acto narrativo -"the narrative transaction" (2005, p. 89) y por ello deben actuar en el texto a través de las formas del autor implícito-narrador y lector implícito-narratario: 
Figura 2. Esquema narratológico de Seymour Chatman

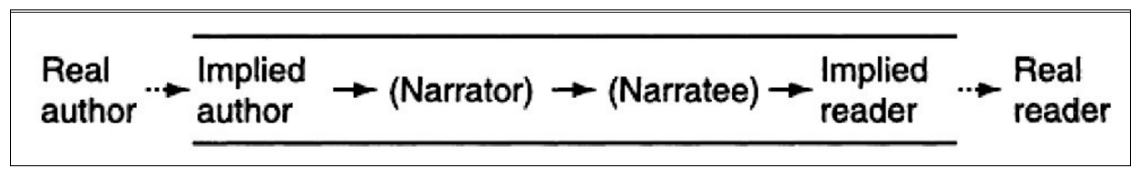

Fuente: Story and Discourse: Narrative Structure in Fiction and Film (1978, p. 151)

Reproducido por Shlomith Rimmon-Kenan (2005, p. 89)

La figura del narrador que transmite la historia no la experimenta, es decir, su actuación pertenece al discurso, no a la historia. Este sería el caso de la voz de Sergi Dies en El Gran Vuelo. Pero, por otro lado, Villafañe y Mínguez afirman: “[E]n ocasiones narrador y personaje coinciden, en cuyo caso resulta difícil separar el universo del discurso del de la historia, pues esta parece a la vez narrada y experimentada por dos figuras superpuestas, pero que habitan un espacio y un tiempo diferentes" (2009, p. 195). Esta figura es, atendiendo a la persona en relación con la historia según la terminología de G.Genette, un narrador homodiegético porque cuenta la historia como participante de la diégesis, en primera persona, por contraposición a un narrador heterodiegético cuando no forma parte de la historia que está relatando. Si además este personaje es protagonista de su relato, se denomina autodiegético (1989. pp. 298-300). Como señala Genette, la relación entre un narrador heterodiegético y homodiegético va necesariamente unida a los niveles narrativos: extradiegético, relator en primer grado que no es un personaje, e intradiegético, cuando sí lo es y el receptor ya no es un narratario o lector, sino otro personaje del relato primero (1989, pp. 284-285 y 302-303).

La voz de María Cazes representa a este personaje de Clara Pueyo que a su vez es narradora de su propia historia a través de la lectura de sus cartas. Aquí no debemos confundir narrador cinematográfico con la voice-over, ya que se trata de un mecanismo a través del que se manifiesta el narrador (Villafañe y Mínguez, 2009, p. 196), pero no es necesariamente el único, pues una técnica muy utilizada en el documental es la narración a través de elementos puramente visuales como fotografías y películas familiares, que son fundamentales en $E l$ Gran Vuelo y en todo el cine de Carolina Astudillo. No podemos escuchar la voz de nuestros muertos, pero la directora hace un ejercicio de memoria poniendo voz a las cartas encontradas de Clara, las que al parecer nunca llegó a enviar: "El estómago ha podido más que el corazón y mi boca debe ir a otros manantiales a buscar el sustento que le hace falta. Salgo del Oasis la próxima semana" (min. 44:50). Podemos interpretar dos esferas de su vida a través de las dos voces: por un lado, lo público, los hechos históricos, las caras de la postguerra, los acontecimientos que se conocen de la vida de la protagonista y de su familia en la voz masculina del narrador; por otro lado, los sentimientos de Clara, lo más privado de su vida como sus motivaciones para alejarse de sus compañeros del cuartel clandestino del Oasis, el enamoramiento y la dramática muerte de su bebé. Se establece así un discurso doblemente dialógico entre la Historia, con mayúscula, y la historia de Clara Pueyo.

Tomamos el sistema de código matemático diseñado por Julia Kristeva para reconocer cómo el sujeto de la narración [Autor/Autora: Carolina Astudillo] desaparece, se hace anónimo [A cero] y se mediatiza a través de sus personajes [él: hombre narrador / ella: Clara Pueyo]. Podríamos afirmar que la directora deja huella de su diálogo con el otro yo a modo de espejo = consigo misma, a través de dos discursos aparentemente enfrentados: el de lo público y el de lo privado. 
Aquí reconocemos una de las principales características del cine-ensayo: la autorreflexividad [2] como herramienta de autoconocimiento. Esta dicotomía -público-Historia / privado-historias- encarna esa ambivalencia de la que habla Julia Kristeva donde coexisten “a la vez 'doble de lo vivido’ (realismo, épica) y 'vivido’ mismo (exploración, lingüística, menipea)” (1981, p. 224). Como hemos referido más arriba, Kristeva destaca el dialogismo inmanente en el discurso histórico. Consideramos que la voz narrativa masculina en El Gran Vuelo no asume el papel autoritario de un ser superior -un Dios-, propio de los textos monológicos, sino que más bien intenta disfrazar esta ambivalencia, ya que podemos entrever que la directora habla a través de él: "La mística revolucionaria sacraliza valores considerados masculinos: coraje, fuerza, dureza y heroísmo. Una duda es signo de debilidad, se exige devoción, sacrificio y entrega por la causa” (min. 34:57). Otro caso se da al inicio de la película, donde con tono profesional de locutor Dies nos presenta las primeras fotografías de Clara: "Acaso le hubiera parecido poco solemne sonreír en el estudio de un fotógrafo. En esa época, las mujeres no solían hacerlo" (min. 02:47) y unos minutos después, la fusión de la autora en el sujeto de la enunciación, el narrador, es más reconocible: "Aquí, lo inquietante es la sonrisa de las otras reclusas. ¿En las fotos oficiales se les obliga a sonreír? ¿O simplemente desde niñas les han enseñado a observarse a sí mismas mientras son observadas?” (min. 03:23). En palabras de Sánchez Noriega podemos afirmar que en El Gran Vuelo: "El cine aparece como espacio mítico capaz de identificaciones y proyecciones del sujeto" (2000, p. 35). En esta reflexión sobre cómo las mujeres son conscientes de ser un objeto de observación desde pequeñas, Carolina está haciendo referencia a uno de los primeros textos fundacionales de la teoría fílmica feminista, el ampliamente conocido Visual Pleasure and Narrative Cinema, artículo escrito por Laura Mulvey y publicado en la revista Screen en 1975. A través del uso de estas dos voces, Carolina Astudillo se desdobla como sujeto de la enunciación en hombre narrador -omnisciente- y, por otro lado, en mujer personaje en representación de Clara Pueyo -testimonios en primera persona-y se revela a ella misma como sujeto del enunciado -autorreflexividad-.

Figura 3. Esquema dialógico de El Gran Vuelo (2014) según el modelo comunicativo de Julia Kristeva en Semiótica I

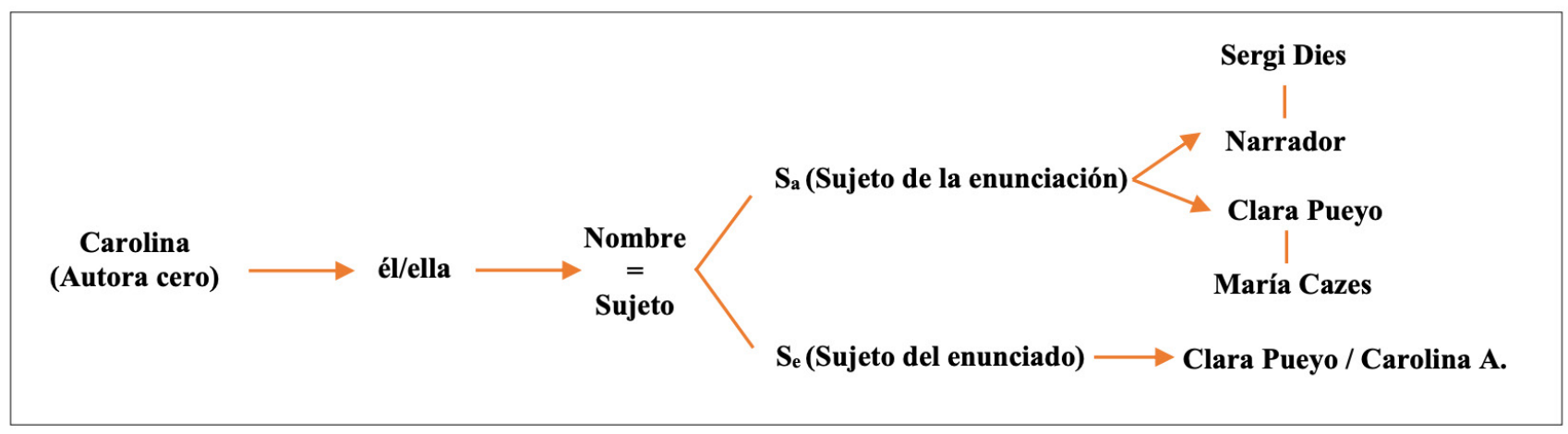

Fuente: Elaboración propia 
El Gran Vuelo presenta una estructura circular; comienza y finaliza con las únicas imágenes que se conservan de Clara Pueyo, como una reivindicación de su existencia, aunque no podamos contar con su voz. También a modo de homenaje, once voces de diferentes mujeres leerán los nombres de las reclusas que fueron fusiladas en el Camp de la Bota entre 1939 y 1940, compañeras algunas de ellas de Clara Pueyo, así como el día exacto de su muerte y su edad, siendo la más joven de 20 años y la más mayor de 60: Carme, Eugenia, Cristina, Ramona, Neus, Dolors, Magdalena, Virginia, Eleonor, Assumpció e Inés.

Figura 4. Tres fotografías de Clara Pueyo Jornet

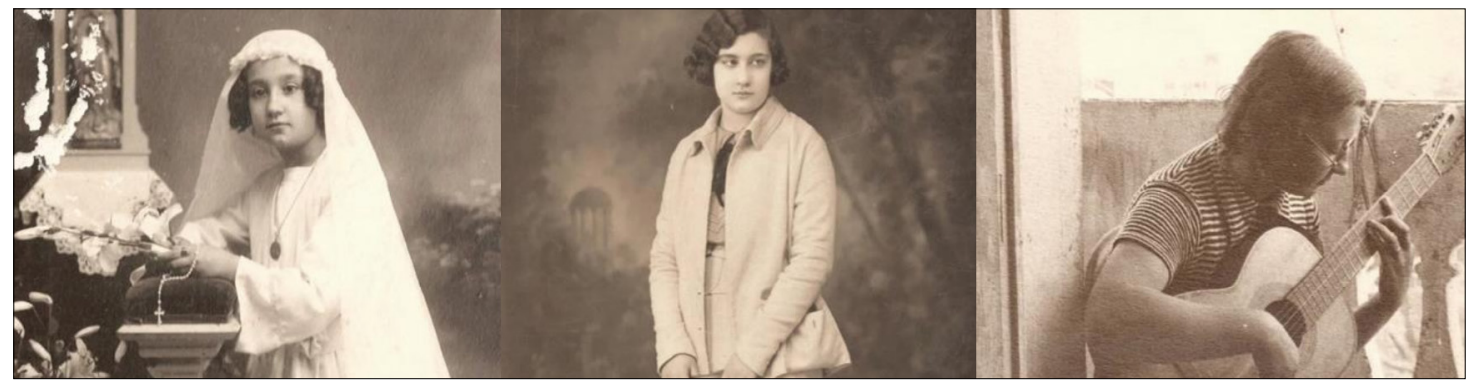

Fuente: El Gran Vuelo (Carolina Astudillo, 2014)

En su siguiente largometraje, Ainhoa, yo no soy esa (2018), Carolina Astudillo nos traslada unos años más adelante, tras la muerte del dictador Francisco Franco, y elige hablarnos de un periodo histórico a través de la vida de una mujer a la que tampoco conoció y que, de la misma forma que Clara Pueyo, plasmó sus inquietudes y sentimientos por escrito. En esta película, la directora explora los años de la llamada transición española, durante los que creció Ainhoa, y los confronta con los años de la dictadura militar de Augusto Pinochet en Chile, donde ella vivía:

Querida Ainhoa, he decidido escribirte aun sabiendo que nunca leerás esta carta. No nos conocimos, pero podríamos haber coincidido. Pertenecemos a la misma generación, semejante y distinta a la vez. Ambas nacimos en la década de los 70, en países separados por la inmensidad de un océano que vivían bajo la dictadura (min. 01:52).

Los primeros años de la vida de Ainhoa Mata Juanicotena quedaron retratados por su padre, obsesionado con grabarlo todo con su pequeña cámara de Super 8: los cumpleaños, las vacaciones en Bera de Bidasoa, pero, sobre todo, la playa: “¿Qué tiene el verano que deja un recuerdo que no se extingue con los años? Abundan las películas familiares filmadas en los meses estivales [...] como si los recuerdos más bellos se condensaran en una estación, el amor incluso” (01:35:00). Más adelante, las fotografías y vídeos con amigos nos mostrarán a una Ainhoa rebelde, con una estética punk tan característica de los locos años ochenta. Sin embargo, será a través de sus diarios como desvelará su carácter sensible, sus episodios depresivos y el sentimiento de estar atrapada. Muchos jóvenes de su generación sufrieron también este desengaño de llegar a la vida adulta tras una adolescencia muy ligada a las drogas, las fiestas y a la esperanza de un futuro brillante que nunca llegó. 
En esta película, es la voz de Carolina la que escuchamos como narradora. La directora interpela a la protagonista, inventa un diálogo entre las dos y se identifica profundamente con sus experiencias hasta el punto de confesar que ella también decidió abortar, al igual que Ainhoa lo había hecho dos veces: "Cuando comencé a escribir el guion de esta película me quedé embarazada. Ni siquiera lo había imaginado. [...] Dos líneas rosas, fue como si estuviese ante un abismo que seduce y aterra. Imagino que pasaste por lo mismo" (01:01:45). Aquí la narradora utiliza la primera persona para formar parte de la historia que está contando, se convierte en una narradora homodiegética llevando al máximo grado la identificación con su personaje protagonista: yo soy como tú. Del mismo modo que al leer los nombres de las reclusas que fueron fusiladas en El Gran Vuelo, en este segundo largometraje, Carolina Astudillo homenajea a otro grupo de mujeres, entre las que se encontraban Simone de Beauvoir, Delphine Seyrig, Marguerite Duras y Agnès Varda. La directora pidió a Mäithé Chansard que leyera para su película un fragmento del Manifiesto de las 343, publicado el 5 de abril de 1971 en la revista Le Nouvel Observateur ${ }^{3}$, y que contenía una lista con las firmas de 343 mujeres francesas, algunas de ellas muy conocidas, que habían abortado cuando todavía era ilegal en el país.

Con este acto de exposición ante la justicia, quisieron reivindicar el derecho al aborto libre.

Figura 5. Esquema dialógico de Ainhoa, yo no soy esa (2018) según el modelo comunicativo de Julia Kristeva en Semiótica I

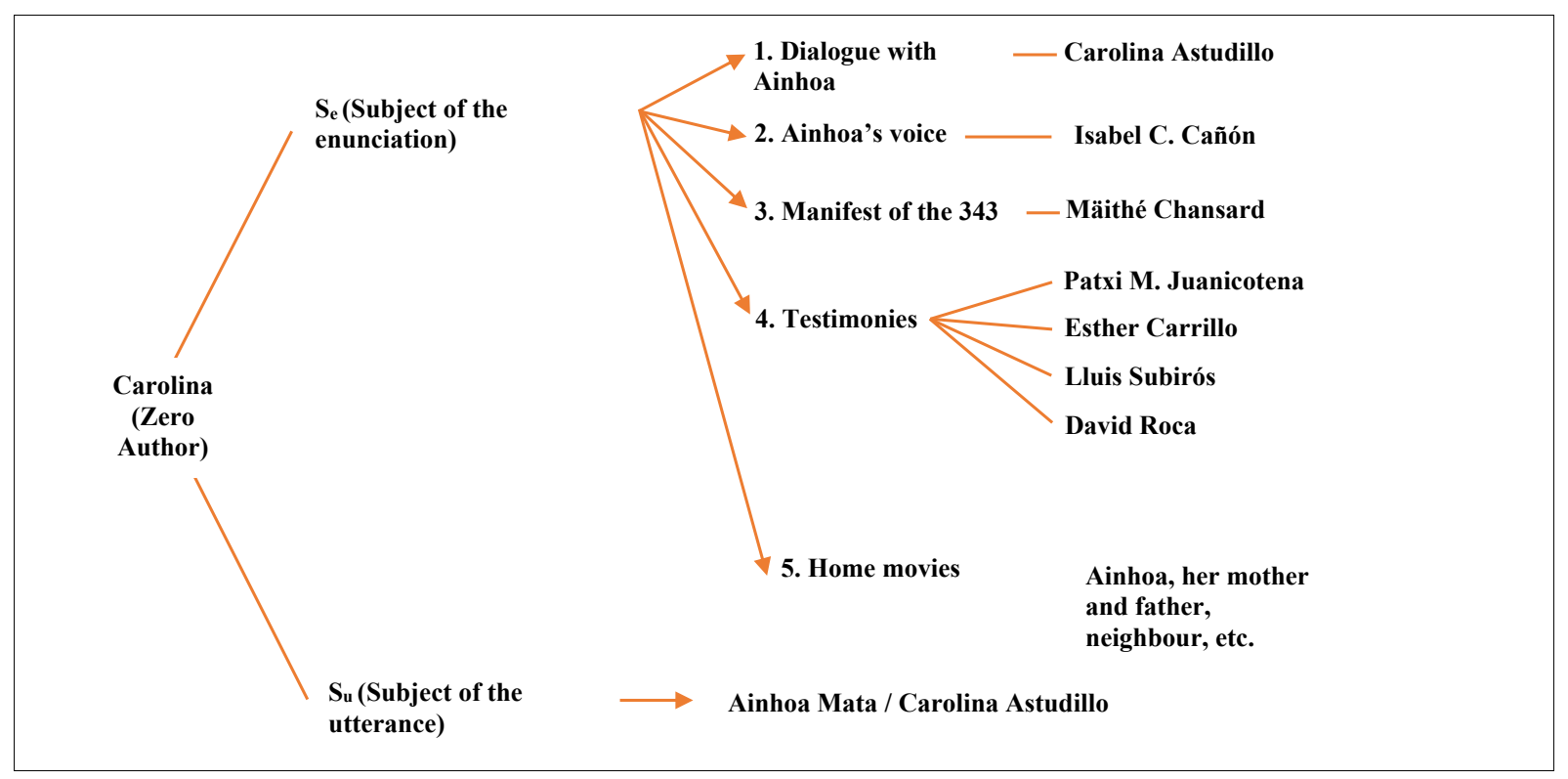

Fuente: Elaboración propia

3 "La complexité des émotions liées à la lutte pour l'avortement indique avec précision notre difficulté d'être, le mal que nous avons à nous persuader que cela vaut le coup de se battre pour nous". Entre las firmantes: Simone de Beauvoir, Catherine Deneuve, Marguerite Duras, Delphine Seyrig, Agnès Varda, Monique Wittig y Françoise Sagan. Le Manifeste des 343 (5 de abril). Nouvel Observateur, 334. Disponible en: https://bit.ly/3jPIg8W 
Del mismo modo que Carolina dialoga con Ainhoa, también lo hace con las personas que la conocieron y cuyos testimonios aparecen en la película, la voz de su hermano Patxi, de sus amigos Esther y Lluis, y de David, una antigua pareja. Al tener la necesidad de dos interlocutores, la voz de Ainhoa adulta será interpretada por la escritora Isabel Cárdenas Cañón, autora de También eso era el verano (2014), un libro que Carolina confiesa que influyó mucho en su proceso creativo para la película. Isabel lee los diarios de Ainhoa con su voz dulce. Junto a estos, aparecerán imágenes rodadas por Carolina en Super 8 de los diarios de Sylvia Plath, Alejandra Pizarnik, Frida Kahlo, Anne Sexton y Susan Sontag. Sánchez Noriega afirma que todo personaje suele convertirse, por estar construido evidentemente por un autor, en su delegado en el texto. También señala que "suele ser frecuente en el cine de autor la existencia de personajes con rasgos comunes" (2000, p. 129). Si bien la alusión de Noriega a personajes recurrentes en el cine de algunos autores se centra en dar ejemplos en películas de ficción, consideramos que de igual forma es una tendencia en el cine documental y en el ensayo fílmico, que a menudo cuentan con una fuerte presencia autoral. Shlomith Rimmon-Kenan, en el capítulo referido a los niveles de la narración y las voces de su Narrative Fiction. Contemporary Poetics (2005), desarrolla varios de los conceptos tratados por Wayne C. Booth (1961, p.67) como la entidad antropomórfica del autor implícito en el texto, es decir, un alter-ego. En palabras de Rimmon-Kenan, esta figura es de quien emanan todas las normas narrativas del conjunto del texto, ella utiliza el término "governing conciousness" (2005, p. 89). A continuación, vuelve a hacer referencia a los estudios de Seymour Chatman (1978, p. 148-150) para aclarar que este autor implícito no es exactamente la voz del narrador. El autor implícito carece de voz, no tiene forma de comunicarse verbalmente si no es a través de un narrador o narradora (2005, p. 90), actúa en el conjunto de la obra donde deja sus huellas de una forma más o menos explícita, pero siempre e inevitablemente intencionada. Será el lector quien tiene en última instancia la responsabilidad de encontrar, de decodificar estos rasgos del autor implícito para llegar a una comprensión profunda del significado del texto. También cabe destacar que de acuerdo con Chatman (1978, p. 150) narrador y narratario no son figuras que se den siempre en cada texto, de ahí que en el esquema reproducido más arriba estén entre paréntesis [Figura 2]. Por otro lado, en el texto fílmico, el autor implícito, aunque carezca de voz, cuenta con una gran variedad de recursos que toman forma en la puesta en escena, entendida como el acto de "desarrollar cada elemento vinculado a su plasmación visual" (Tranche, 2015, p. 50). Carolina Astudillo combina elementos visuales y auditivos a través de múltiples voces en sus películas, con un especial hincapié en el camuflaje de su punto de vista en otros personajes-narradores.

\section{Conclusiones}

Desde su primer cortometraje, De Monstruos y faldas (2008), Carolina se ha interesado por la construcción de un cine-manifiesto, o cine-rescate, que ponga en práctica la construcción artística de una genealogía de las mujeres. Aunque solo dos de sus títulos giran en torno a la cárcel de Les Corts y hacen alusión al personaje de Clara Pueyo Jornet ${ }^{4}$-De Monstruos y faldas y El Gran Vuelo (2014)- en todos sus títulos encontramos personajes femeninos con roles significativos. En su últi-

4 Canción a una dama en la sombra (2021) se encuentra en fase de postproducción. Es su tercer largometraje y toma como línea argumental la muerte de uno de los hermanos de Clara Pueyo en Mauthausen. Se centra en las cartas que envió a su esposa y en el rol de las mujeres que esperaron como en el mito de Penélope. 
mo largometraje, esta identificación con la historia de un personaje desconocido como Ainhoa Mata Juanicotena se hace universal y permite su actualización:

La idea de hacer este entramado, esta tela de araña entre los textos de mujeres con las experiencias femeninas que siempre están presentes en los diarios, en los diarios de personas anónimas como en los diarios de escritoras conocidas y eso relacionarlo con el diario de Ainhoa, entonces ahí como que era casi político (C. Astudillo. Comunicación personal, entrevista 13 de enero 2021).

La constante mezcla de testimonios e imágenes en distintos formatos nos muestra a retazos la vida de Ainhoa, con múltiples líneas narrativas que se cortan y vuelven a surgir, con reflexiones que no persiguen una conclusión, al igual que se hace imposible conocer las verdaderas razones por las que la protagonista se quitó la vida. Carolina construye así un discurso asistemático [3] propio del ensayo cinematográfico, que en palabras de Antonio Weinrichter "no establece conclusiones, sino que ensaya reflexiones" (2007, p. 13).

Como hemos citado en el marco teórico del estudio, varios autores han reflexionado sobre las fronteras difusas entre la ficción y el documental, o más ampliamente la no ficción (Carrera y Talens, 2018; Cerdán y Torreiro, 2007; Ward, 2005). Suzanne Keen hace referencia al indicador paratextual, tomando el término de Gerard Genette (1997), que califica un libro, antes de haberlo leído, como una narrativa de no ficción (2015, p. 126). Todo paratexto anuncia las intenciones del autor o autora, de la casa productora y su estrategia, así como del propio texto, generando unas expectativas en el lector. Por lo tanto, en muchas ocasiones, la diferencia entre ficción y no ficción es puramente pragmática: "labeling and categorizing performed by others shape most readers' certainties about the nonfiction they read" (2015, p. 126) ${ }^{5}$. Si aplicamos esta disyuntiva terminológica al cine, Mínguez aporta tres motivos por lo que esta categorización puede resultar problemática: por ser conceptos trasladados del ámbito literario; por un deseo o necesidad de agrupar obras de naturaleza muy diversa, lo que no resulta adecuado en un entorno de estudio científico y, por último, debido a que ya no son aplicables en el contexto de las nuevas tecnologías y por lo tanto se aconseja que su uso sea reformulado (2014, p. 127, citado en Pérez Nieto, 2020, p. 728). Keen encuentra rasgos propios de la ficción en obras literarias que presentan la forma de una narrativa factual, es decir, que hace referencia a lo real (p. 128). En su libro El relato documental, Pilar Carrera y Jenaro Talens advierten que lo importante en la clasificación de una película dentro de la no ficción no es a qué hace referencia, puesto que una producción canónica de ficción hollywoodiense puede tratar el mismo tema, sino a cómo se ha construido el relato para producir lo que ellos denominan "efecto referencial" (2018, p. 50). Proponen este término como instrumento analítico, abriendo así un camino a los futuros estudios sobre cine documental, no sin olvidar desde qué latitudes se está llevando a cabo: "Y este tiene que ver con la mencionada institucionalización de modalidades de recepción para las diversas tipologías de relato que configuran lo que podemos denominar el Occidente del sentido" (2018, p. 50). No podemos evitar aquí hacer referencia al sistema arborescente del pensamiento occidental desarrollado por Deleuze y Guattari en Rizoma, la necesidad de categorización árbol-raíz contra las infinitas relaciones de una forma de pensamiento en rizoma-canal: "Problema de la escritura: siempre se necesitan expresiones anexactas para designar algo exactamente [...]. Si recurrimos a un dualismo de modelos es para llegar a un proceso que recusaría cualquier

5 El etiquetado y la categorización realizadas por otros conforman las certezas de la mayoría de los lectores sobre la no ficción que leen” (2015, p. 126). 
modelo" (1977, p. 47). En el centro de estos dilemas clasificatorios situamos al ensayo audiovisual, que presenta una hibridación de características formales y narrativas. Resulta por lo tanto muy difícil llegar a una definición cerrada de lo que hemos considerado una forma de hacer cine en lugar de un género. David Bordwell destacó en 1989 la necesidad de aplicar categorías -framing (p. 146) - al cine para su estudio, la mayoría asociadas con la idea de género. Sin embargo, para Bordwell la teoría cinematográfica no había logrado un acuerdo general sobre la definición de tales géneros: "Indeed, all the results so far indicate that no such conditions can be found. Theorists have been unsuccessful in producing a coherent map of the system of genres" (1989, p. 147) ${ }^{6}$. En la actualidad, consideramos que esto sigue vigente y que la aplicación de categorizaciones estrictas sobre una muestra de películas empobrece los análisis, eliminando ciertos aspectos periféricos en cada una de ellas. El ensayo fílmico nace con el planteamiento de una serie de preguntas por parte de un autor o autora y prioriza el proceso de creación desde un cuestionamiento de las estructuras narrativas y formales (Pérez Nieto, 2020, p. 729). Su libertad formal lo aleja del cumplimiento de un "efecto de sentido" referencial como explican Carrera y Talens (2018, pp. 8-9), por lo que puede presentar rasgos propios de la ficción. Los efectos a nivel referencial dependerán de cómo se haya organizado el discurso: "Lo que produce la creencia no es la visión, ni lo que hace ver son las creencias. A la imagen y a la creencia solo se llega a través de un acto retórico" (2018, p. 10).

En el cine de Carolina Astudillo, a la presencia de un discurso asistemático se suma la característica de autorreflexividad [2] estudiada en relación con el ensayo audiovisual. En sus películas se da prioridad al proceso de construcción del relato fílmico como herramienta de autoconocimiento, en un ejercicio de memoria no solo histórica, sino también familiar. Así, la puesta en común de materiales privados como películas domésticas y fotografías, tanto propias como ajenas, construye un retrato social al mismo tiempo que revela el entorno íntimo de la autora. En palabras de Efrén Cuevas (2010):

[E]se reciclaje del metraje doméstico puede aportar, habitualmente desde una clave autobiográfica, miradas iluminadoras sobre la condición humana, pistas para la reconstrucción de la identidad personal, necesitada de esa vuelta a los orígenes -a las raíces familiares- como marco para la comprensión de las cuestiones identitarias, más aún cuando esas raíces surgen de cruces étnicos, religiosos o nacionales (p. 26).

Por último, queremos resaltar la característica de pacto ensayístico [6] presente en El Gran Vuelo (2014) y Ainhoa, yo no soy esa (2018). Ambos títulos, al igual que el resto de creaciones de Carolina, apelan al espectador con un uso sistemático de la voz. Como acabamos de referir, la autora regala parte de su vida íntima, como por ejemplo su decisión de abortar. Con esto ella da, es generosa, pero también pide una participación activa del público, estableciendo así lo que hemos llamado pacto ensayístico. Podemos relacionar este fenómeno comunicativo con la teoría de la empatía narrativa que Suzanne Keen desarrolla en Empathy and the Novel (2007). La identificación con los personajes se basa en un cierto grado de empatía con las situaciones que el texto presenta, aunque los personajes sean aparentemente muy distintos al espectador. Esta empatía del lector, o del público, tiene su contraparte, como desarrolla Keen, en la empatía del autor (2007, p. 124-125). Si bien Keen centra su análisis de la relación empática en la literatura de ficción, consideramos que el hecho de que un escritor, o creador, desarrolle una especial capacidad de comprensión en la vida real gracias a la creación de per-

6 De hecho, todos los resultados hasta ahora indican que no se pueden encontrar tales condiciones. Los teóricos no han conseguido elaborar un mapa coherente del sistema de géneros" (1989, p. 147). 
sonajes, es también aplicable a obras cinematográficas como las películas de Carolina Astudillo. En ellas, la directora ve y siente a través de la investigación sobre unos personajes de la vida real, intenta comprenderlos y en este proceso dialoga con ellos. Es a través de la voz y de las imágenes cómo la autora nos acerca vidas pasadas. A su empatía con estos personajes se suma la nuestra hacia ella, creándose un flujo comunicativo de ida y vuelta, de identificaciones y de reflexión sobre el pasado para comprender mejor el presente.

\section{Referencias bibliográficas}

Alter, N. (1996). The Political Im/perceptible in the Essay Film: Farocki's Images of the World and the Inscription of War. New German Critique, 68, 165-192. https://bit.ly/2N9wMkK

Ávila, C. y Linares, F. (2010). Algunas nociones sociocríticas y la dimensión cultural de las palabras. Sociocriticism, XXV, 1-2, 93-118. http://bit.ly/3tmLLIk

Bajtín, M. (1978). Esthétique et théorie du roman. Gallimard. [Trad. al castellano: Bajtín, M (1989). Teoría y estética de la novela. Taurus].

Bal, M. (1985). Narratology: Introduction to the Theory of Narrative. University of Toronto Press.

Barthes, R. (1966). Introduction à l'analyse structurale des récits. Communications, 8, 1-27. http://bit.ly/36Cljyf

Bellour, R. ([1990]2012). Between-the-Images. JRP/Ringier.

Benveniste, É. (2004). Problemas de lingüística general. Tomo II. Siglo XXI Editores.

Bohórquez, D. (1997). Julia Kristeva: teoría, proceso e interpretación del sentido. Signa. Revista de la Asociación Española de Semiótica, 6. Biblioteca Virtual Miguel de Cervantes. http://bit.ly/36ziwsg

Booth, W.C. (1961). The Rhetoric of Fiction. The University of Chicago Press.

Bordwell, D. (1989). Making Meaning. Inference and Rhetoric in the Interpretation of Cinema. Harvard University Press.

Bordwell, D. (1996). La narración en el cine de ficción. Paidós.

Carrera, P. y Talens, J. (2018). El relato documental. Cátedra.

Català, J. M. (2014). Estética del ensayo. La forma ensayo, de Montaigne a Godard. Publicacions de la Universitat deValència.

Català, J. M. (2019). Pensar el cine de pensamiento. Ensayos audiovisuales, formas de una razón compleja. En Mínguez, N. (ed.) Itinerarios y formas del ensayo audiovisual, 13-59. Gedisa.

Cerdán, J. y Torreiro, C. (eds.) (2007). Al otro lado de la ficción. Trece documentalistas españoles contemporáneos. Cátedra. Chatman, S. (1978). Story and Discourse: Narrative Structure in Fiction and Film. Cornell University Press.

Chatman, S. (1990). Coming to Terms. The Rhetoric of Narrative in Fiction and Film. Cornell University Press.

Chicharro, A. (2007). Una introducción a los estudios sociocríticos y sus relaciones con las teorías semiolingüísticas y sociosemióticas. En Utrera, M. V. y Romero, M. (eds.) Estudios Literarios in Honorem Esteban Torre. Universidad de Sevilla. Cros, E. ([1995] 2005). Le sujet culturel. Sociocritique et psychanalyse. L'Harmattan. 
Cros, E. (2009). La sociocrítica. Arco Libros.

Cuevas, E. (2010). La casa abierta. El cine doméstico y sus reciclajes contemporáneos. Ocho y Medio.

Deleuze, G. (1986). La imagen-tiempo. Estudios sobre cine 2. Paidós.

Deleuze, G. y Guattari, F. (1977). Rizoma. Introducción. Pre-Textos.

Gaudreault, A. y Jost, F. (1995). El relato cinematográfico. Paidós.

Genette, G. (1970). Fronteras del relato. En Barthes, R., Greimas, A. J., Bremond, C., Gritti, J., Morin, V., Metz, C., Todorov. T. y Genette. G. Análisis estructural del relato, 193-203. Tiempo Contemporáneo.

Genette, G. (1982). Palimpsestes. La littérature au second degré. Éditions du Seuil.

Genette, G. (1983). Nouveau discours du récit. Éditions du Seuil.

Genette, G (1989). Figuras III. Lumen.

Genette, G. (1997). Paratext: Thresholds of Interpretation. Cambridge University Press.

Keen, S. (2007). Empathy and the novel. Oxford University Press.

Keen, S. (2015). Narrative Form. Revised and Expanded $2^{\text {nd }}$ Edition. Palgrave Macmillan.

Kristeva, J. ([1969] 1981). Semiótica 1. Fundamentos.

Kristeva, J. ([1967] 1981). Bajtín, la palabra, el diálogo y la novela. En Semiótica 1. Espiral/Fundamentos.

Kristeva, Julia (1997, 25 sept.-1 oct.). Une désinformation. Nouvel Observateur, 1716, 122. https://bit.ly/3pHvw6C

Mínguez, N. (2014). Más allá del marco referencial. Ficción y no ficción en la cultura audiovisual digital. Telos, 99, 126-134. http://bit.ly/3oH8n31

Mínguez, N. y Manzano, C. (2020). El ensayo en el audiovisual español contemporáneo: definición, producción y tendencias. Communication \& Society, 33(3), 17-32. Doi: 10.15581/003.33.3.17-32 https://bit.ly/3r2Z2V4

Mulvey, L. ([1975] 1999). Visual Pleasure and Narrative Cinema. En Braudy, L. y Cohen, M. (eds.) Film Theory and Criticism: Introductory Readings, 833-844. Oxford University Press.

Pasolini, P. P. y Rohmer, E. (1971). Cine de poesía contra cine de prosa. Anagrama.

Pérez Nieto, E. (2020). Cine para una genealogía de las mujeres. Rasgos ensayísticos en las películas de Virginia G. del Pino, Tatiana Huezo y Carolina Astudillo. En Suárez Villegas, J. C., Martínez Pérez, N. y Panarese, P. (eds.) Cartografía de los micromachismos: dinámicas y violencia simbólica, 725-741. Dykinson.

Rascaroli, L. (2017). How the Essay Film Thinks. Oxford University Press.

Rimmon-Kenan, S. (2005). Narrative Fiction. Contemporary Poetics. $2^{\text {nd }}$ edition. Taylor \& Francis e-Library.

Sánchez Noriega, J. L. (2000). De la literatura al cine. Teoría y análisis de la adaptación. Paidós.

Sokal, A. y Bricmont, J. (1999). Impostures intellectuelles. Le Livre de Poche.

Todorov, T. (1966). Les catégories du récit littéraire, Communications, 8, 125-151. http://bit.ly/36C1jyf 
Tranche, R. (2015). Del papel al plano. El proceso de la creación cinematográfica. Alianza Editorial.

Villafañe, J. y Mínguez, N. (2009). Principios de teoría general de la imagen. Ediciones Pirámide. Anaya.

Ward, P. (2005). Documentary: The margins of reality. Wallflower Press.

Weinrichter, A. (ed.) (2007). La forma que piensa. Tentativas en torno al cine-ensayo. Fondo de Publicaciones del Gobierno

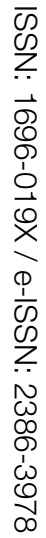
de Navarra. 